\title{
Entrepreneurship as a Key Resolution for Declining Business Dynamism
}

\author{
Cheng Tseng \\ University of Chicago \\ Chien-Chi Tseng \\ Morgan State University
}

This paper investigates the causes and effects of declining business dynamism in the United States and identifies potential solutions that can be utilized to stimulate business dynamism through a comprehensive literature review. While the main focus of this paper is on business dynamism, the research also addresses entrepreneurial challenges and incentives, since active entrepreneurial activity is critical to maintaining a dynamic business environment. The study explores six factors-insufficient access to capital, regulations and tax compliance, employee/employer mismatch, economic uncertainty, generational views of entrepreneurship, and effects of corporations and other large enterprises-that influence entrepreneurial activity.

\section{INTRODUCTION}

From the late 1970 s to the early $21^{\text {st }}$ century, there have been a perilous decline in startup rate and a slow but increasing firm exit rate in the US. A study done by the Brookings Institution, citing data from the US Census Bureau, found that the firm entry rate fell by nearly fifty percent in roughly three decades, from 1978 to 2010 (Hathaway and Litan, 2014). Even more surprising is the fact that the level of business deaths increased in proportion while business births dropped, which was especially significant after 2006. 2008 saw the business death rate exceed the business birth rate for the first time in over thirty years. Several other studies have confirmed this decline in business dynamism and startup rates, especially in the high technology sector (Decker, et al., 2016; Haltiwanger et al., 2014). Also, such a persistent decline in net firm formation could also result in a thinner job market, as well as potentially detrimental effects on overall economic productivity.

Such findings - including the decline in net firm formation and business consolidation - point toward a need to identify the various causes of declining business dynamism and create solutions that could help stimulate entrepreneurial activity. This research first identified keywords to use in the literature search: business dynamism and entrepreneurship. Second, the study identified the databases to search; all of the several electronic databases available, including the US Federal Government's electronic library and other journal and book sources, were used, as well as Google Scholar and additional institutional resources. The research also explains how these factors can lead to declining business dynamism.

Figure 1 presents the firm entry and exit rate, between 1978 and 2011. The dark blue line represents the firm entry rate. The light blue line represents the firm exit rate. Notice how the firm exit rate exceeds the firm entry rate during 2008. 


\section{FIGURE 1}

\section{THE FIRM ENTRY AND EXIT RATE, BETWEEN 1978 AND 2011}

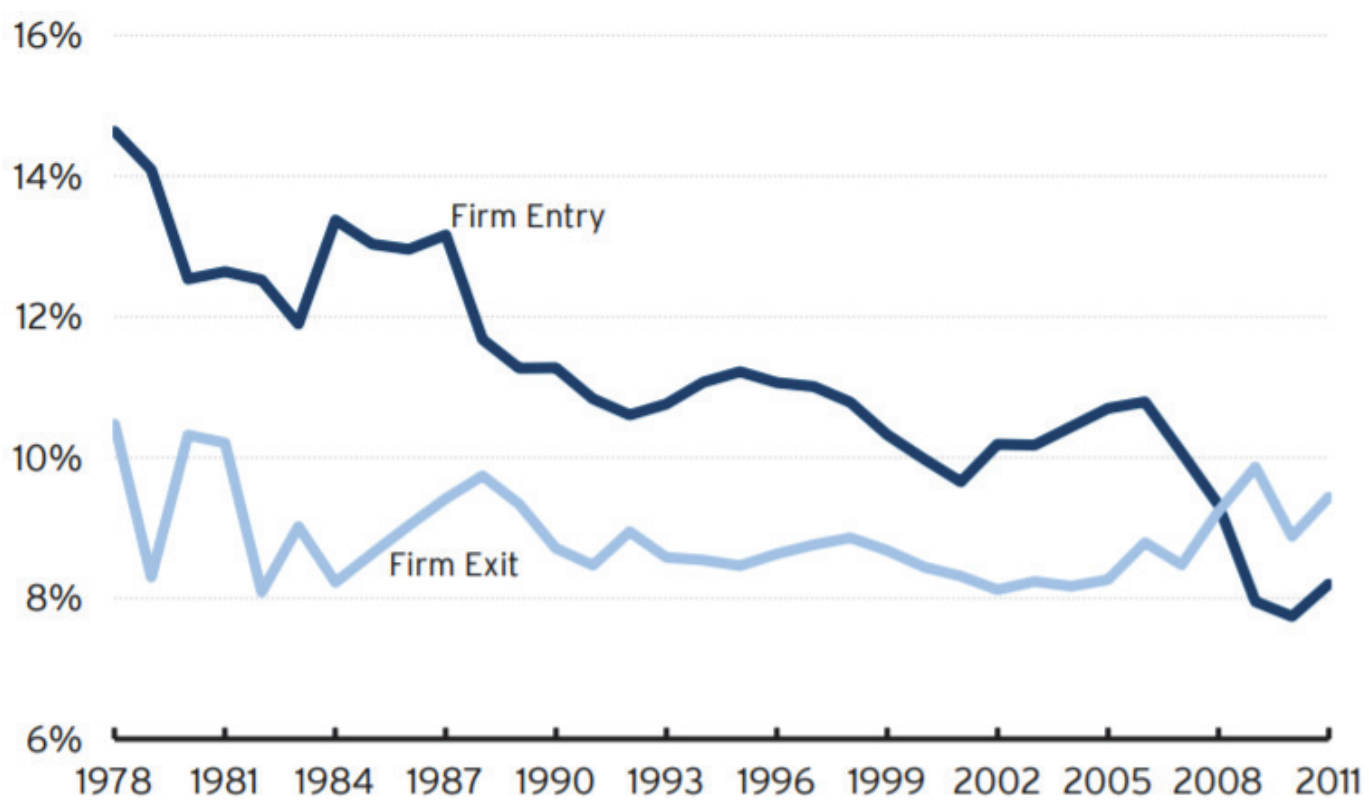

Source: Hathaway, I. and Litan, R. (2014), "Declining business dynamism in the United States: A look at states and metros."

The concept of business dynamism has been explored in the past (Decker et al., 2014; Haltiwanger et al., 2014; Sutter, 2002), and many sources claim that entrepreneurship has been on a steady decline for many years (Haltiwanger et al., 2012; Prescott and Ohanian, 2014). The effects of continually declining business dynamism and new firm formation are threatening, since the two factors can have serious implications on the US and the worldwide economy. With such high stakes at hand, it is thus imperative to understand the reasons behind declining business dynamism, which is often synonymous with the challenges of starting a new business.

These reasons include but are not limited to: insufficient access to capital, onerous taxes and regulations, difficulty finding employees with the right skills and talents, effects of larger, more mature firms, and economic uncertainty. Certain trends point to a potential discrepancy in entrepreneurial behaviors of different age groups as well. The Baby Boomers, born between 1946 and 1964, innovated ferociously compared to the Millennials, who did not innovate nearly as much (Simon and Barr, 2015).

\section{THEORY DEVELOPMENT}

\section{Business Dynamism}

According to Hathaway and Litan (2014), business dynamism is the process by which firms are continually born, fail, expand, and contract. As some jobs are created, others are destroyed, and still, others are turned over. It is gauged by two measures: firm entry and job reallocation. As more firms enter the market and as more people move to new areas in the country in search of jobs, business dynamism increases (Haltiwanger, 2012). On the other hand, as fewer firms enter the market and as fewer people reallocate in search of jobs, industry consolidation becomes increasingly widespread, ultimately leading to a decline in business dynamism (Lettieri, 2016). Business dynamism is, frequently, disruptive; but it is also necessary for long-run economic growth. The creative destruction that this process entails creates new markets and value networks that displace established market leaders and alliances. 


\section{Entrepreneurship}

Entrepreneurship is a topic widely discussed in the literature (Drucker and Maciariello, 2015; Gartner 2007; Shane and Venkataramen, 2000; Stevenson and Jarillo, 2007). Kent et al. (1982) defined entrepreneurship as the creation of new business enterprises by individuals or small groups, with the entrepreneur assuming the role of society's major agent for change and initiating the industrial progress that leads to wider cultural shifts.

It has been often regarded that entrepreneurship is the hero of capitalism. Indeed, it is because of entrepreneurship and intrepid individuals known as entrepreneurs that innovative ideas become profitable businesses (Kuratko, 2016). Four major dimensions make up this unique process: individual, organizational, environmental, and process. Entrepreneurs recognize and seize opportunities by turning them into marketable ventures, using their capitals to implement these ideas.

\section{Causes of Declining Business Dynamism}

Insufficient Access to Capital

The biggest concerns for aspiring entrepreneurs are capital-related. Getting enough money to start and sustain a business is usually extremely difficult, especially if the entrepreneur's credit history is less than ideal. But even people with perfect credit do not have enough startup capital. Why is that?

Well, one reason is the relatively small capital deployment by venture capitalists and angel investors in new Pre-A stage firms. Mattermark's (2015) Startup Funding Report reveals that the size of seed investments in Pre-A firms, though having increased \$400 million between 2014 and 2015, did not nearly match the growth rates of Series A, B, C, and Late stage investment sizes. Besides, much of this relatively small investment is given to technology firms.

\section{Strict Government Regulations and Tax Compliance Measures}

Government regulations and tax compliance measures affect small businesses, especially startups, significantly. First, regulatory compliance exerts a disproportionately large burden on small businesses; small businesses have neither the economies of scale nor the organizational capacity to deal with such regulations and the fixed costs resulting from these regulations can be shared over more revenue in large businesses (Lettieri, 2016).

Second, government regulations also make small businesses less competitive against foreign businesses, since the regulatory costs in most foreign countries are much lower.

Third, the increasing number of government regulatory measures creates uncertainty for small business owners, who often put off hiring new workers and investing in capital enhancements until they see the impact of the new regulations.

Fourth, new regulations often produce unintended consequences: many ill-structured policies, like the new health care law or the Clean Air Act by the EPA, led to heavy compliance costs for small businesses.

\section{Employee/Employer Mismatch}

The inability of finding employees with the right skill set may at least be partly responsible for the decline in US entrepreneurial activity. This inability can be attributed to two reasons: shrinking population growth and faulty immigration policies.

Immigrants contribute to the entrepreneurial activity and economic growth in the United States as well. Immigrants generally have a much greater inclination to become entrepreneurs than native-born Americans. In fact, in the high-tech sector, immigrants are twice as likely to start new businesses and high-tech patent discoveries (Hathaway and Litan, 2014; Wadhwa et al., 2007). However, some aspects of the current US foreign policy discourage immigration. Although there are programs, such as the EB-5 visa, created to stimulate job creation and capital investments by foreigners, they are too limited in scope to have any significant impact. 


\section{Economic Uncertainty}

Economic uncertainty is a fear that all entrepreneurs face. While almost everyone would benefit from an economic boom, the gloomy prospects of an economic downturn haunt virtually all businesses in the US, especially small, new businesses. A few intricate factors that directly affect entrepreneurial activity will almost certainly follow economic uncertainty: decreased business opportunities, decreased optimism, and greater incentive to find more stable employment.

To illustrate, following to the Great Recession, new firm formation suffered a precipitous drop. Statistics from the Kauffman Foundation show that over 180 new businesses were created out of 100,000 total firms in 2006, before the Great Recession, but less than 125 new businesses were created out of 100,000 total firms in 2010, during the aftermath of the Great Recession (Fairlie, 2014). The Great Recession will have a lasting impact on many, especially millennials who sought employment during this period. Not only does this extreme economic uncertainty affect people's preference for risk-taking, which may have generated issues later on, but the uncertainty also diminishes their financial capability to start a business (Lettieri, 2016).

\section{Differing Generational Views of Entrepreneurship}

According to Wilmoth (2016) and many other studies, Millennials are the least entrepreneurial generation in recent history. Compared to the 5.4 percent of Generation Xers and 6.7 percent of Baby Boomers who reported self-employment as their primary occupation at age 30, less than 4 percent of Millennials reported self-employment at age 30.

To further demonstrate this entrepreneurial discrepancy, Simon and Barr (2015) found a strong contrast between the shares of households headed by adults younger than 30 that held stakes in private businesses in 1989 and 2013. Whereas over 10 percent of households in 1989 held stakes in private businesses, only 3.6 percent of the household fitting the established criteria existed in 2013. Furthermore, a Kauffman Foundation study discovered that young people launched 35 percent of all startups in 1996. But, by 2014, only 18 percent of startups were launched by young people (Fairlie, 2014).

\section{Effects of Corporations and Other Large Enterprises}

The claim that large businesses crowd out smaller, less competitive businesses may not be too surprising. After all, large firms possess a disproportionate amount of resources, have better funding, and enjoy the economies of scale which new firms lack.

The increasing consolidation within industries also leads to widespread monopolizing on talented workers, who realize the advantages of working at an established firm rather than becoming an entrepreneur. Not only the perks and pay are usually better, but also the amount of risk associated with working for an established firm is less as well.

\section{METHODS}

This research first identified key words to use in the literature search: enterprise dynamism and entrepreneurship. Second, the study identified the databases to search; all of the several electronic databases available, including the US Federal Government's electronic library and other journal and book sources, were used, as well as Google Scholar and additional institutional resources.

Lettieri's (2016) paper was used as the foundation of this study, with additional input emerging from the search to provide information on the different causes and consequences of declining enterprise dynamism and entrepreneurial activity. The literature enhanced our understanding of the significance of entrepreneurship and the relationship between entrepreneurship and economic growth. The literature also gave us insight into potential solutions that could stimulate entrepreneurial activity and, thus, enterprise dynamism.

In addition, Kuratko (2016) provided information used for this paper. His book, Entrepreneurship: Theory, process, and practice, not only helped formulate my definition of entrepreneurship, but it also 
helped define entrepreneurial challenges and the importance of entrepreneurship. Finally, Kahn's (2010) findings were used to analyze the relationship between generational factors and enterprise dynamism.

\section{RESULTS}

\section{Consequences of Declining Business Dynamism}

Lower Innovation Performance

A direct implication of declining business dynamism is a lower innovation performance for both entrant and incumbent firms. Quite obviously, innovation and entrepreneurship are intricately connected and the number of startups created every year depends on the existence of a healthy entrepreneurial environment.

If the incentives for starting a new business are diminished, as seen through the period of declining business dynamism, firm entry rates will follow this decline. Such a decline is alarming, since startups are disproportionately likely to introduce disruptive innovations and radically new products (Lettieri, 2016).

\section{Less Competition}

The significance of Hathaway and Litan's (2014) research lies in the result: less competition. With less competition from new businesses, a less entrepreneurial environment exists in which incumbents enjoy heightened market power and barriers to entry. Established incumbents are also less inclined to innovate and more inclined to raise prices (Lettieri, 2016).

Thus, declining business dynamism tends to have a snowball effect; less competition causes increased business consolidation, which in turn harms innovation performance and economic productivity. Figure 2 indicates that, between 1978 and 2011, firms in every age group under 16 years have been steadily declining while the share of firms 16 years or older have increased from 23 percent to over 34 percent.

\section{FIGURE 2}

\section{THE DISTRIBUTION OF FIRMS BY AGE OVER TIME BETWEEN 1978 AND 2011}

$40 \%$

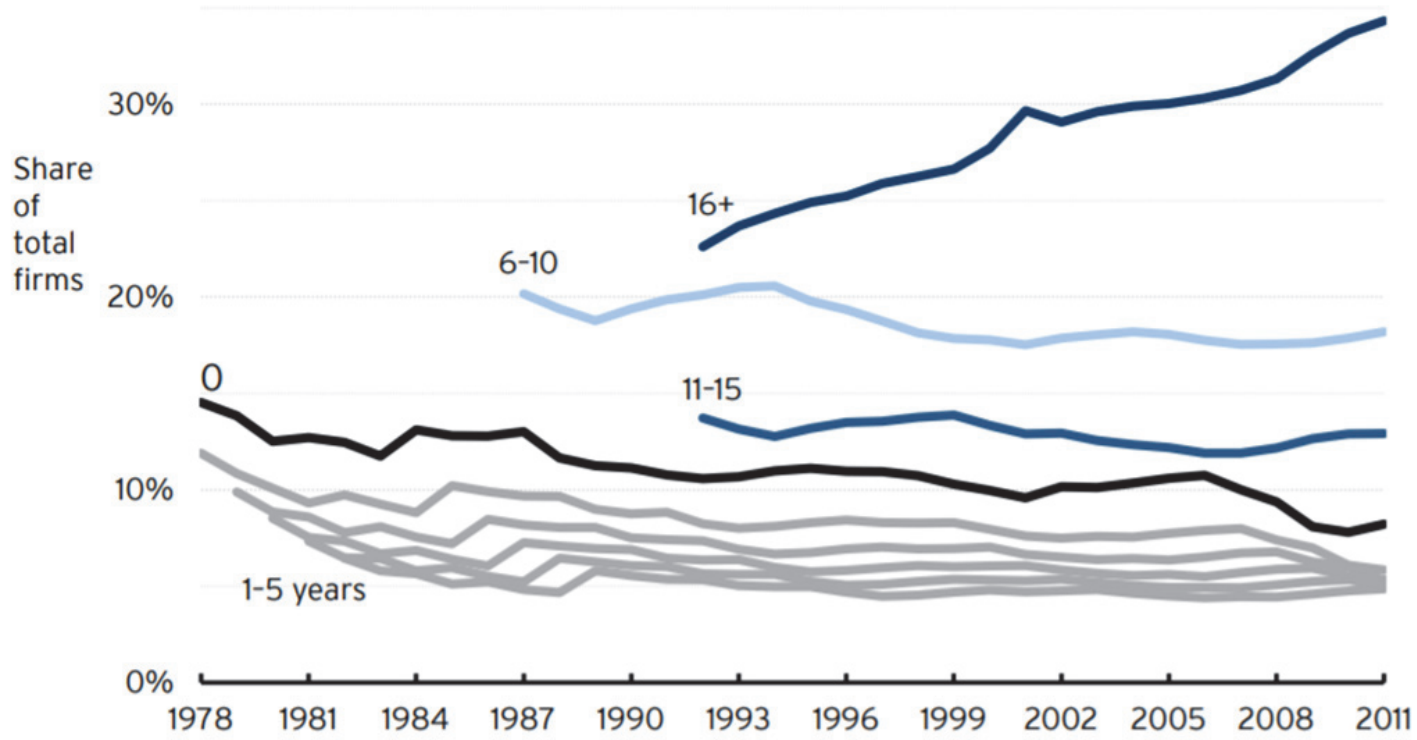

Source: Hathaway, I. and Litan, R. (2014), "The other aging of America: The increasing dominance of older firms." 


\section{Declines in Economic Productivity}

While this decline in economic productivity could simply be attributed the dearth of time-saving inventions, perhaps declining business dynamism could be another justification. As the economy becomes increasingly dominated by large, established firms, small and new firms are crowded out. These small and new firms are the source of innovation in the US because they not only introduce radical new ideas, but they also carry out a disproportionate share of disruptive innovations (Lettieri, 2016).

Essentially, small businesses keep the economy efficient and productive. As new businesses commercialize innovations and disrupt concentrated industries, startups ensure that the economy allocates its resources to the most valuable and efficient use (Lettieri, 2016).

\section{Increase in the Level of Inequality between Different Social Classes}

Although leading businesses, and their leaders and investors, are enjoying an era of prosperity from entrepreneurship, most working- and middle-class Americans are not indulging in the same prosperity. Instead, a long, arduous journey awaits these less fortunate Americans, who work exceedingly hard to succeed in the entrepreneurial area.

According to the Economic Competitiveness Survey of Rivkin et al. (2015), entrepreneurship is becoming a luxury good and growing farther out of reach for middle income Americans. It is now more accessible to the well-connected, better-educated individuals but less to Americans in general. Historically a path to middle-class and prosperity, entrepreneurship is fast becoming a way for the wealthy to become even more affluent.

\section{Fewer Job Opportunities}

Declining business dynamism and the less fluid nature of the job market affect disadvantaged populations the most. Demand for labor from startups and young firms is crucial for young, less educated, and marginally attached workers, since they provide monetary incentives and career benefits (Lettieri, 2016). Davis and Haltiwanger (2014) asserted that reduced labor market fluidity can lengthen jobless spells, reduce participation rates, and diminish employability through several channels. The lengthening of jobless spells can affect workers dramatically by lessening their human capital and weakening incentives to work in the future.

New firms' demand for labor, on the other hand, pushes older businesses to raise wages. In light of declining business dynamism, stagnating wages, and a lack of new businesses, policymakers should pay more attention to the implications of the current US labor market trends.

\section{Widening Geographic Disparities}

According to Lettieri (2016), the collapse in new firm formation will eventually create an uneven geography in the United States consisting of large areas with a missing generation of employment providers, investors, and taxpayers. The implications of declining entrepreneurial activity in these areas are large and negative: economic distress and deterioration will follow and lead to unstable business dynamics. Startup hubs, like Silicon Valley, will garner extraordinary advantages since they will become the only sites of innovation.

The growing disparities between these startup hubs and other less innovative parts of the US can cause traditionally high rates of geographic mobility - a factor that helped to balance divergences in economic wellbeing across regions - to fall. As access to economic opportunity in expensive coastal cities become increasingly limited, so too does entrepreneurship's potential for working- and middle-class individuals.

\section{Solutions to Declining Business Dynamism}

Social Factors Affecting Entrepreneurs

We found the most important factors in encouraging entrepreneurial behavior are society-driven. Although legal and regulatory changes can affect an individual's decision to become an entrepreneur, the primary reason for starting a new business comes from that individual's motivations. One method of 
encouraging entrepreneurial behavior is to understand specific personality types associated with developing entrepreneurs.

Ten personal characteristics are often exhibited by entrepreneurs (although there may be other alternate personality traits as well):

1. Achievement - entrepreneurs possess a high necessity for achievement

2. Authority - entrepreneurs dislike authority, except for authority imposed within themselves

3. Independent Thinkers - entrepreneurs seek to innovate and think independently. They are not concerned about reaching a consensus.

4. Working style-entrepreneurs are intuitive and self-motivated workers who are willing to take bold steps after careful consideration.

5. Failure - entrepreneurs often do not consider failure as a personal shortcoming, but as an event that can be conquered.

6. Innate belief - entrepreneurs believe that their work will control the outcome of their business, not luck or some other inexistent forces.

7. Risk-entrepreneurs are risk takers.

8. Motivation - entrepreneurs are motivated by bringing their vision to reality.

9. Work experience - entrepreneurs are often dissatisfied with their previous work experience.

10. Life path interruptions - many entrepreneurs began their journeys after experiencing a serious interruption in their lives, such as an illness, economic displacement, or war.

\section{Legal and Regulatory Incentives}

There are several ways the state and federal governments can incentivize startups and young businesses. Antitrust Law incentives, for example, can prevent corporate consolidation and enable startups and other young firms to compete with larger, more established firms.

Regulatory relief - such as devoting more time and resources to compliance assistance, reducing the number of regulations, expanding certain tax and pension fund rules, and making specific exceptions for young businesses - can significantly benefit entrepreneurial activity by assisting young businesses in dealing with a variety of local, state, and federal regulations. The government could also establish additional programs aimed at stimulating entrepreneurial activity across the nation.

\section{Taxation Reform}

Two tax principles - tax treatment of costs and tax treatment of gains-could encourage entrepreneurial activity. By allowing startups and other young businesses easier methods of obtaining financial capital, they will have more opportunities to compete with older, more established firms. The first principle is tax treatment of costs, which focuses on deductions and expenses of businesses. Tax treatment of costs can be changed through the following methods ${ }^{1}$ :

1. "Expensing" investments - allow more investments to be deducted as expenses in the year they are incurred rather than treating them as capital investments that depreciates over several years.

2. Rate of depreciation - decrease the number of years required for depreciation or change the baskets of depreciation.

3. Methods of depreciation-structure the tax system to allow "accelerated" depreciation instead of "straight-line" depreciation.

4. Investment Tax Credits - for every dollar spent, subtract a fraction of a dollar from the taxes owed. This method could encourage certain types of business activities, such as investment in disadvantaged areas and hiring targeted social groups.

5. "Carry-forward" provisions for losses - allow the net losses of firms to be carried-forward to offset net profits earned in later years. 


\section{Foreign Policy Reform}

According to Hathaway and Litan (2014), Immigrants are much more likely to become an entrepreneur, especially if they are in the high-tech industry. Many immigrants are highly motivated and skilled workers who will overcome any obstacles to achieve their dreams. Foreign immigrants are so motivated that they are more than twice as likely to start a business compared to native-born Americans.

However, US foreign policy toward immigrants, particularly those who are highly skilled, is not the most favorable. A few ways to boost our nation's employment opportunities and business dynamism, therefore, could be accomplished through raising H-1B visa quotas for immigrant entrepreneurs and expanding the number of STEM education/green card visas.

\section{Promotion of Entrepreneurship Education}

Perhaps the best entrepreneurial environments are found at colleges and universities. To promote education in entrepreneurship, colleges and universities could learn from the three-stage Student Entrepreneurial Encouragement Model of Jansen et al. (2015). The first stage of this model, the education stage, is characterized by colleges and universities striving to wake dormant entrepreneurs by providing supportive staff and facilities, highlighting role models and success stories, and offering introductory entrepreneurship courses.

In the second stage, the stimulation stage, colleges and universities could support the entrepreneurial process by supporting founding team formation, providing mechanism for idea validation, providing pitching opportunities, supporting business plan creation, and enabling prototype development.

In the final stage, the incubation stage, colleges and universities provide funding, offer mentoring, provide networking opportunities, and establish accelerator programs until startups can survive independently.

\section{SUGGESTION AND IMPLICATIONS}

From this research, we analyzed the effects of declining business dynamism in the US and discovered many potential inhibitors to entrepreneurial activity. With these entrepreneurial challenges in mind, we then identified solutions that policymakers should focus on to alleviate these challenges and stimulate business dynamism. We hope to shed light on this important economic indicator and help enhance productivity in the process.

In seeking to understand the declining business dynamism trend described in the previous studies (Decker et al., 2016; Haltiwanger et al., 2014; Hathaway and Litan, 2014) and the US Census Bureau annual reports, the research explored six potential causes. These six potential causes - insufficient access to capital, strict government regulations and tax compliance measures, employee and employer mismatch, economic uncertainty, differing generational views of entrepreneurship, effects of corporations and other large enterprises - pose challenges for developing entrepreneurs, limiting their capacity to innovate and contribute to business dynamics. Thus, they serve as the foundation of our study and the baseline for many of our proposed solutions for future research.

Finally, this research proposed several implications and solutions that policymakers should take the initiative to explore. The implications and solutions we propose involve taxation reform, other legal and regulatory incentives, social factors experienced by entrepreneurs, foreign policy reform, and the promotion of entrepreneurship education.

These implications should serve as the foundation for entrepreneurial policy reforms because they offer insight into the entrepreneur's journey through many perspectives. By learning about entrepreneurial challenges, entrepreneurial incentives, and the impacts of active entrepreneurial behavior, society as a whole could be in a better position to jumpstart the business dynamism of the US. 


\section{CONCLUSION}

Promotion of entrepreneurship education would be the most important implications for developing an entrepreneurial environment. To facilitate an entrepreneurial environment and a healthy business dynamism in the US, policymakers should focus on several important factors, including: taxation reform, social factors affecting entrepreneurs, access to capital, foreign policy reform, and the promotion of entrepreneurship education.

Perhaps the best entrepreneurial environments are found at colleges and universities. Colleges and universities offer a multitude of resources, including entrepreneurial incubators and specific programs that can expose students to new ideas and innovative methods. Students work according to their schedules, and they do not need to worry about the profit-oriented procedures of corporate laboratories. Colleges and universities contribute to a special type of entrepreneurship known as academic entrepreneurship, and they can strongly encourage students to launch new business ventures.

There are challenges and obstacles for entrepreneurial development. The obstacles faced by entrepreneurs include insufficient access to capital, excessive regulations and compliance measures, difficulty in finding highly-skill workers, economic uncertainty, generational anomalies, and effects of corporations and large enterprises (economies of scope implications). These challenges are daunting, and not only can they hinder entrepreneurial pursuits, but they can also lead to several other problems.

To promote education in entrepreneurship, colleges and universities could learn from the three-stage Student Entrepreneurial Encouragement Model of Jansen et al. (2015). The first stage of this model, the education stage, is characterized by colleges and universities striving to wake dormant entrepreneurs by providing supportive staff and facilities, highlighting role models and success stories, and offering introductory entrepreneurship courses. In the second stage, the stimulation stage, colleges and universities could support the entrepreneurial process by supporting founding team formation, providing mechanism for idea validation, providing pitching opportunities, supporting business plan creation, and enabling prototype development. In the final stage, the incubation stage, colleges and universities provide funding, offer mentoring, provide networking opportunities, and establish accelerator programs until startups can survive independently.

\section{ENDNOTE}

1. Note: Source from The Emerson Associates: Methods of Encouraging Entrepreneurial Activity, available at: http://www.emerson-associates.com/encouragingentrepreneurs.pdf

\section{REFERENCES}

Davis, S. J., \& Haltiwanger, J. (2014). Labor market fluidity and economic performance. Retrieved from http://citeseerx.ist.psu.edu/viewdoc/download?doi=10.1.1.566.6492\&rep=rep1\&type=pdf

Decker, R., Haltiwanger, J., Jarmin, R., \& Miranda, J. (2014). The role of entrepreneurship in US job creation and economic dynamism. The Journal of Economic Perspectives, 28(3), 3-24.

Decker, R. A., Haltiwanger, J., Jarmin, R. S., \& Miranda, J. (2016). Where has all the skewness gone? The decline in high-growth (young) firms in the US. European Economic Review, 86, 4-23.

Drucker, P., \& Maciariello, J. (2015). Innovation and Entrepreneurship. London, UK: Routledge.

Fairlie, R. W. (2014). Kauffman index of entrepreneurial activity 1996-2012. Retrieved from https://escholarship.org/uc/item/9sd4w816

Gartner, W. B. (2007). Is there an elephant in entrepreneurship? Blind assumptions in theory development. In A. Cuervo, D. Ribeiro, and S. Roig (Eds.), Entrepreneurship Concepts, Theory and Perspective (pp. 229-242). New York: Springer.

Haltiwanger, J. (2012). Job creation and firm dynamics in the United States. In J. Lerner and S. Stern (Eds.), Innovation Policy and the Economy, 12, pp. 17-38. Chicago, IL: University of Chicago Press. 
Haltiwanger, J., Jarmin, R., \& Miranda, J. (2012). Where Have All the Young Firms Gone? Retrieved from

https://www.kauffman.org/ /media/kauffman_org/research\%20reports\%20and\%20covers/2012/0 5/bds_2012.pdf

Haltiwanger, J., Hathaway, I., \& Miranda, J. (2014). Declining business dynamism in the US hightechnology sector. Retrieved from

https://www.kauffman.org/ /media/kauffman_org/research\%20reports\%20and\%20covers/2014/0 2/declining_business_dynamism_in_us_high_tech_sector.pdf

Hathaway, I., \& Litan, R. (2014). Declining business dynamism in the United States: A look at states and metros. Retrieved from http://www.truthandaction.org/wpcontent/uploads/declining_business_dynamism_hathaway_litan.pdf

Hathaway, I., \& Litan, R. (2014). The other aging of America: The increasing dominance of older firms. Retrieved from https://www.brookings.edu/wpcontent/uploads/2016/06/other_aging_america_dominance_older_firms_hathaway_litan.pdf

Hathaway, I., \& Litan, R. (2014). What's driving the decline in the firm formation rate? A partial explanation. Retrieved from https://www.brookings.edu/wpcontent/uploads/2016/06/driving_decline_firm_formation_rate_hathaway_litan.pdf

U.S. Census Bureau (2018). Figure 7. Annual homeownership rates for the United States by age group: 1982-2017. Retrieved from https://www.census.gov/housing/hvs/data/charts/fig07.pdf

Jansen, S., van de Zande, T., Brinkkemper, S., Stam, E., \& Varma, V. (2015). How education, stimulation, and incubation encourage student entrepreneurship: Observations from MIT, IIIT, and Utrecht University. The International Journal of Management Education, 13(2), 170-181.

Kent, C. A., Sexton, D. L., \& Vesper, K. H. (1982). Encyclopedia of entrepreneurship. Paper presented at the University of Illinois at Urbana-Champaign's Academy for Entrepreneurial Leadership Historical Research Reference in Entrepreneurship, Champaign, IL. Retrieved from https://ssrn.com/abstract $=1496225$

Kuratko, D. F. (2016). Entrepreneurship: Theory, Process, and Practice. Boston, MA: Cengage Learning.

Lettieri, J. W. (2016). America without entrepreneurs: the consequences of dwindling startup activity. Retrieved from https://www.sbc.senate.gov/public/_cache/files/0/d/0d8d1a51-ee1d-4f83-b740515e46e861dc/7F75741C1A2E6182E1A5D21B61D278F3.lettieri-testimony.pdf

Prescott, E. C., \& Ohanian, L. E. (2014). Behind the productivity plunge: fewer startups. Retrieved from https://www.wsj.com/articles/behind-the-productivity-plunge-fewer-startups-1403737197

Rivkin, J. V., Mills, K. G., Porter, M. E., Norton, M. I., \& Weiss, M. B. (2015). The challenge of shared prosperity: Findings of Harvard Business School's 2015 Survey on U.S.

Competitiveness. Retrieved from http://www.hbs.edu/competitiveness/Documents/challenge-ofshared-prosperity.pdf

Shane, S., \& Venkataraman, S. (2000). The promise of entrepreneurship as a field of research. Academy of Management Review, 25(1), 217-226.

Simon, R., \& Barr, C. (2015). The Wall Street Journal. Endangered species: Young US entrepreneurs. Retrieved from http://opportunityamericaonline.org/wpcontent/uploads/2015/01/ENDANGERED-SPECIES1.pdf

Stevenson, H. H., \& Jarillo, J. C. (2007). A paradigm of entrepreneurship: Entrepreneurial management. In A. Cuervo, D. Ribeiro, and S. Roig (Eds.), Entrepreneurship (pp. 155-170). Berlin, Heidelberg: Springer.

Sutter, K. M. (2002). Business dynamism across the Taiwan Strait: the implications for cross-strait relations. Asian Survey, 42(3), 522-540.

Tollison, R. D. (1982). Rent seeking: A survey. Kyklos, 35(4), 75-602.

Wadhwa, V., Saxenian, A., Rissing, B. A., \& Gereffi, G. (2007). America's new immigrant entrepreneurs: Part I. Duke Science, Technology and Innovation Paper, 23, 41.

Wilmoth, D. (2016). The missing millennial entrepreneurs. Small Business Exchange, 31(49), 1, 7, \& 9. 